\title{
In memoriam: Julio López Gallardo (22 September 1941 - 3 May 2020)
}

\author{
Gerardo Fujii-Gambero, Juan Carlos Moreno-Brid, Carlo Panico and \\ Martín Puchet Anyul \\ Facultad de Economía, Universidad Nacional Autónoma de México, Mexico City, Mexico
}

'But if with our testimony we succeed to transmit to the next generation an ember of its ashes, our effort wouldn't be utterly vain.'

Stefan Zweig

Julio López Gallardo, one of the most distinguished Latin American economists, passed away in Paris on 3 May 2020. We write this in memoriam with a mixture of profound sadness for his departure, deep gratitude for his friendship and the desire to celebrate with all members of the ROKE community his extraordinary academic career.

Julio was born in Osorno, Chile, on 22 September 1941. He was baptized as Julio Stefan, in honour of the great author Zweig, whose books would become an important source of inspiration and pleasure in Julio's adult life. He undertook his undergraduate studies in Commercial Engineering (as the BA in economics was then referred to in the Southern Cone) at the Universidad de Chile, located in Santiago, where the Economic Commission for Latin America and the Caribbean (ECLAC) had its headquarters. Consequently, Julio benefited from the teaching of some of the key thinkers of Latin American Structuralism: Raúl Prebisch, Juan Noyola, Celso Furtado, Aníbal Pinto, Osvaldo Sunkel and Pedro Vuskovic. His BA dissertation was on the relationship between income distribution and economic growth, a problem that would concern him during his entire life. In the mid 1960s, Ignacio Pérez Salgado, full professor and dean of the recently inaugurated Faculty of Economics of the Universidad de Concepción, invited him to join the staff of young lecturers.

$\mathrm{He}$ and his wife Judith Villavicencio - endearingly known as Pelusa - then left for Poland to carry out their graduate studies. Julio went to the University of Warsaw, where Michał Kalecki was his $\mathrm{PhD}$ supervisor and he also had close contact with Ignacy Sachs. In this phase of his academic formation in Europe, he also worked for a year under Sylos Labini's guidance at the University of Rome.

Julio and Pelusa returned to Chile in 1969, the year before the Unidad Popular won the presidential elections with Salvador Allende as candidate. Julio joined the left wing of the young Christian-Democrats, supporting Allende; among them were José Miguel Insulza, Luis Maira and Carlos Montes. All of them made outstanding contributions to the return of democracy in the country. Julio was appointed as advisor to the Copper Corporation; then and now Chile's most important state-owned enterprise. Always committed to academia, he also lectured in Concepción and, at his alma mater, the Universidad de Chile. The brutal military coup forced Julio to go underground, hiding in different places in the country for three years. He fled to Venezuela in 1976 and worked at the Foreign Trade Institute. He remained there for about twelve months, finally safe from the persecution in Chile, and moved to Cuba in 1977, joined by 
Pelusa and their two little daughters, Manuela and Antonia. In September 1978, the López-Villavicencio family moved to Mexico. They enriched Mexico and were enriched by it. They all took Mexican citizenship.

Julio joined the Faculty of Economics of the Universidad Nacional Autónoma de México (UNAM), invited by two of his former students, Arturo Huerta and Eduardo Gonzalez. By then Julio was a formidably trained economist with a rather unique academic, professional and human experience. Julio soon gained recognition at UNAM as an outstanding lecturer and brilliant researcher on both applied and theoretical issues. In addition, he was always available for engaging discussions with colleagues as well as students, eager to learn something new. His mentorship qualities and commitment were remarkable. His lectures were always packed. The students he mentored enjoyed outstanding careers in the public or private sector or in academia. Some of his most dedicated ones - including his daughter Antonia - actually co-authored papers with Julio in top heterodox journals. Julio always expressed his appreciation of UNAM, its atmosphere of freedom of research and the support he received.

With such an intellectual background, intelligence and capacity for hard work, Julio made a large number of contributions to different aspects of economics. His graduate training with Kalecki marked Julio's personal and professional life. He wrote a number of books on Kalecki's contributions, including a major intellectual biography which became a key reference in international academic circles. Besides his permanent fascination with the history of economic thought, Julio had the talent and commitment to combine path-breaking theoretical work with empirical analysis. He mainly focused on Latin America's challenging and still elusive quest for inclusive and sustained economic development.

A solid formation in economic theory and interest in applied econometrics allowed him to make substantial contributions in several fields of economics. Important themes in his research were financial liberalization and crises in emerging economies, the links between exports and economic growth, and the effects of trade on the industrial structure and employment, inter alia. Following the tradition of Latin American Structuralism, Julio devoted attention to the asymmetric links between industrial and agricultural development and the policies to boost long-term economic growth.

His gratitude and love for Mexico permeated his academic career, leading him to write important pieces on the Mexican economy. In fact, he kept publishing relevant papers on Mexico's economic problems even in his later years when he was living in Paris, where he and Pelusa retired and joined their daughters who have successful careers in Biology and in Economics.

Distinguished academics like José Valenzuela, his long-time friend from schooldays in Santiago; Flor Brown and Lilia Domínguez at the Postgraduate School; Carlos Ibarra, Armando Sánchez, Moritz Cruz, José Nabor Carrillo and Verónica de Jesús Romo, once his students; Clemente Ruiz Durán, Rolando Cordera and Carlos Tello, his close accomplices in UNAM's academic life, as well as us four, were fortunate in having him as a close friend. All those who had the good fortune to have him as a colleague, teacher or mentor miss him. His extraordinary intellectual legacy remains as a guide, as a key road-map to help in the formation of current and future economists. We will never forget, not only the brilliant economist, but the kind man with a warm and welcoming attitude, who loved his family and was always open for stimulating conversations on economics, literature, music and cinema, and the personal concerns of his friends. Thank you dear friend! ¡Gracias a la vida por conocerte! 


\section{REFERENCES}

\section{Selected articles and chapters}

López Gallardo, Julio (1966), 'La relación producto-inversión y la tasa óptima de inversión', El Trimestre Económico, 33(132), 687-708.

López Gallardo, Julio (1971), 'La estrategia económica del Gobierno de la Unidad Popular', Cuadernos de la Realidad Nacional, Universidad Católica de Chile, 9(September), 69-86.

López Gallardo, Julio (1972), 'Sobre la construcción de la nueva economía', Cuadernos de la Realidad Nacional, Universidad Católica de Chile, 13(July), 39-53.

López Gallardo, Julio (1983), 'La distribución del ingreso en México: estructura y evolución', El Trimestre Económico, 50(200), 2227-2256.

López Gallardo, Julio (1985), 'The post-war Latin American economies: the end of the long boom', Banca Nazionale del Lavoro Quarterly Review, 38(154), 233-260.

López Gallardo, Julio (1986), 'Michal Kalecki e a Teoría da Demanda Efectiva', Revista de Economía Política, 6(3), 58-68.

López Gallardo, Julio (1993), 'Transferencias externas, ajuste interno y potencial de crecimiento', in J. Ros (ed.), La edad de plomo del desarrollo latinoamericano, Mexico City: Fondo de Cultura Económica, pp. 147-175.

López Gallardo, Julio (1997), 'Mexico's crisis: financial modernization and financial fragility', Banca Nazionale del Lavoro Quarterly Review, 50(201), 165-185.

López Gallardo, Julio and Tracy Mott (1999), 'Kalecki versus Keynes on the determinants of investment', Review of Political Economy, 11(3), 291-301, doi: 10.1080/095382599107020.

López Gallardo, Julio (1999), 'Les perspectives de croissance en Amerique Latine: une reflexion inspiree par la theorie de M. Kalecki', Mondes en Developpement, 106, 106-137.

López Gallardo, Julio (2002), 'Two versions of the principle of effective demand: Kalecki and Keynes', Journal of Post Keynesian Economics, 24(4), 609-622.

López Gallardo, Julio, J.C. Moreno-Brid and Martín Puchet (2006), 'Financial fragility and financial crisis in México', Metroeconomica, 57, 365-388, doi: 10.1111/j.1467-999X.2006.00249.x.

López Gallardo, Julio, Armando Sánchez and Aris Spanos (2011), 'Macroeconomic linkages in Mexico', Metroeconómica, 62(2), 356-385, doi: 10.1111/j.1467-999X.2010.04114.x.

López Gallardo, Julio (2018), 'Growth dilemmas in open middle-income economies: a reflection on Mexico's recent experience', Review of Keynesian Economics, 6(3), 333-351.

\section{Books: a selection}

López Gallardo, Julio (1991), La economía del capitalismo contemporáneo: teoría de la demanda efectiva, Mexico City: UNAM-DIANA.

López Gallardo, Julio (1991), Teoría del crecimiento y economías semi-industrializadas, Mexico City: UNAM.

López Gallardo, Julio (2008), La Economía de Michal Kalecki y el Capitalismo Actual: Ensayos de Teoría Económica y Economía Aplicada, Mexico City: Fondo de Cultura Económica.

López G., J. and M. Assous (2010), Michal Kalecki, Great Thinkers in Economics Series, Basingstoke, UK: Palgrave Macmillan.

López Gallardo, J. (2016), Tiempo de cambios: Las tres últimas décadas de la economía mexicana, Mexico City: Facultad de Economía, UNAM. 